\title{
Investigation on the Structure and Electrochemical Properties of La-Ce-Mg-Al-Ni Hydrogen Storage Alloy
}

\author{
Yuqing Qiao, ${ }^{1,2}$ Jianyi Xi, ${ }^{2}$ Minshou Zhao, ${ }^{2}$ Guangjie Shao, ${ }^{2}$ \\ Yongchun Luo, ${ }^{3}$ and Limin Wang ${ }^{1}$ \\ ${ }^{1}$ State Key Laboratory of Rare Earth Resources Utilization, Changchun Institute of Applied Chemistry, CAS, Changchun 130022, China \\ ${ }^{2}$ College of Environmental and Chemical Engineering, Yanshan University, Qinhuangdao, Hebei 066004, China \\ ${ }^{3}$ Department of Materials Science and Engineering, Lanzhou University of Technology, Lanzhou, Gansu 730050, China
}

Correspondence should be addressed to Yuqing Qiao; qiaoyq@ysu.edu.cn and Limin Wang; lmwang@ciac.jl.cn

Received 28 October 2013; Accepted 23 November 2013

Academic Editor: Xinqing Chen

Copyright (C) 2013 Yuqing Qiao et al. This is an open access article distributed under the Creative Commons Attribution License, which permits unrestricted use, distribution, and reproduction in any medium, provided the original work is properly cited.

\begin{abstract}
Structure and electrochemical characteristics of $\mathrm{La}_{0.96} \mathrm{Ce}_{0.04} \mathrm{Mg}_{0.15} \mathrm{Al}_{0.05} \mathrm{Ni}_{2.8}$ hydrogen storage alloy have been investigated. X-ray diffraction analyses reveal that the $\mathrm{La}_{0.96} \mathrm{Ce}_{0.04} \mathrm{Mg}_{0.15} \mathrm{Al}_{0.05} \mathrm{Ni}_{2.8}$ hydrogen storage alloy consisted of a (La, $\mathrm{Mg}$ ) Ni ${ }_{3}$ phase with the rhombohedral $\mathrm{PuNi}_{3}$-type structure and $\mathrm{LaNi}_{5}$ phase with the hexagonal $\mathrm{CaCu}_{5}$-type structure. TEM shows that the alloy is multicrystal with a lattice space $0.187 \mathrm{~nm}$. EDS analyse shows that the content of $\mathrm{Mg}$ is $3.48 \%$ (atom) which coincide well with the designed composition of the electrode alloy. Electrochemical investigations show that the maximum discharge capacity of the alloy electrode is $325 \mathrm{mAh} \mathrm{g}^{-1}$. The alloy electrode has higher discharge capacity within the discharge current density span from $60 \mathrm{~mA} \mathrm{~g}^{-1}$ to $300 \mathrm{~mA} \mathrm{~g}^{-1}$. Electrochemical impedance spectroscopy measurements indicate that the charge transfer resistance $R_{\mathrm{T}}$ on the alloy electrode surface and the calculated exchange current density $I_{0}$ are $0.135 \Omega$ and $1298 \mathrm{~mA} \mathrm{~g}^{-1}$, respectively; the better eletrochemical reaction kinetic of the alloy electrode may be responsible for the better high-rate dischargeability.
\end{abstract}

\section{Introduction}

La-Mg-Ni system alloys are promising materials owing to their higher electrochemical capacity compared to $\mathrm{AB}_{5}$-type alloys; however, the poor cycling stability and HRD of the La$\mathrm{Mg}-\mathrm{Ni}$ hydrogen storage alloys have prevented it from being practically used as electrode alloys for $\mathrm{Ni}-\mathrm{MH}$ battery [114]. According to the literature [15], the capacity degradation during cycling of La-Mg-Ni based hydrogen storage electrode alloy is influenced mainly by two factors: the passivation due to the formation of $\mathrm{La}(\mathrm{OH})_{3}$ and $\mathrm{Mg}(\mathrm{OH})_{2}$ on the alloy surface and the accelerated corrosion rate of the active components due to the large molar volume of hydrogen $V_{\mathrm{H}}$ of the alloy hydrides. As the alloy electrode with a large $V_{\mathrm{H}}$ undergoes a large cell volume expansion/contraction during charge/discharge cycle, a higher degree of pulverization resulted and thus more surface area is exposed to the corrosive electrolyte, which would lead to a lower cycling stability [16-18].

The partial substitution of $\mathrm{Al}$ for $\mathrm{Ni}$ in $\mathrm{La}-\mathrm{Mg}-\mathrm{Ni}$ based alloy can improve the cycling stability due to the noticeable decrease in the cell volume expansion rate $(\Delta V / V)$ on hydriding $[19,20]$. According to the literature [21], Al was helpful to the formation of $\mathrm{LaNi}_{5}$ phase in $\mathrm{La}_{0.67} \mathrm{Mg}_{0.33} \mathrm{Ni}_{3.0-x} \mathrm{Al}_{x}(x=$ $0,0.1,0.2,0.3)$ hydrogen storage alloys. $\mathrm{LaNi}_{5}$ phase with $\mathrm{CaCu}_{5}$ type appeared when $\mathrm{Al}$ was added. The increase of $\mathrm{Al}$ content leads to an increase of content of $\mathrm{LaNi}_{5}$ phase, and the main phase of the alloy is $\mathrm{LaNi}_{5}$ phase with $x=$ 0.3 . According to the literature $[22,23]$, rare earth elements (such as Dy and Pr) are helpful to decrease the cell volume of $\mathrm{LaNi}_{5}$ phase. For $V$-based solid solution alloy [24], the addition of Ce can improve the dynamic performance, which makes the charge transfer resistance $\left(R_{\mathrm{T}}\right)$ decrease and the exchange current density $\left(I_{0}\right)$ increase markedly. Just for 


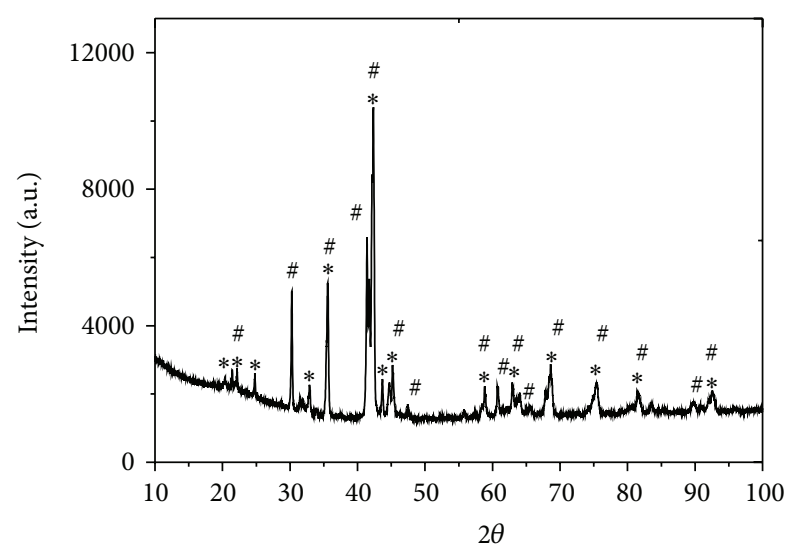

${ }^{*}(\mathrm{La}, \mathrm{Mg}) \mathrm{Ni}_{3}$ phase

FIGURE 1: X-ray diffraction patterns of $\mathrm{La}_{0.96} \mathrm{Ce}_{0.04} \mathrm{Mg}_{0.15} \mathrm{Al}_{0.05} \mathrm{Ni}_{2.8}$ alloy.

those considerations, $\mathrm{Al}$ has been used to partly substitution for $\mathrm{Ni}$, Ce has been used to partly substitution for $\mathrm{La}$, and the structure and electrochemical properties of the La-Ce-MgAl-Ni hydrogen storage electrode alloy have been investigated in this paper.

\section{Experimental}

$\mathrm{La}_{0.96} \mathrm{Ce}_{0.04} \mathrm{Mg}_{0.15} \mathrm{Al}_{0.05} \mathrm{Ni}_{2.8}$ hydrogen storage electrode alloy was prepared by induction melting under argon and then remelted to ensure for homogeneity. The purity of the individual starting metal was higher than 99.5 mass\%. The prepared electrode alloy was mechanically crushed to particles and then pulverized to a fine powder of about 300 mesh, and the sample powder was used for XRD, TEM, and electrochemical characteristics. Crystal structure of La-Ce-Mg-AlNi hydrogen storage electrode alloy was investigated by XRD (CuK $\alpha$, Si internal standard) on Rigaku D/max 2500pc X-ray diffraction meter using JAD5 software and by TEM on JEM2010 .

The metal hydride electrode was prepared by pressing the mixture of alloy powder with carbonyl nickel powder in a weight ratio of $1: 5$ into a tablet with a diameter about $10 \mathrm{~mm}$ and a thickness about $1.5 \mathrm{~mm}$. The electrochemical properties were performed on a DC-5 battery testing instrument using a half-cell system which consists of a metal hydride electrode as the negative electrode and a sintered $\mathrm{Ni}(\mathrm{OH})_{2} / \mathrm{NiOOH}$ electrode with excess capacity in $6 \mathrm{~mol} \mathrm{~L}^{-1} \mathrm{KOH}$ electrolyte solution; the cut-off voltage for discharge was $0.8 \mathrm{~V}$.

Electrochemical impedance spectroscopy (EIS) was used to clarify the kinetic properties of dehydrating action, such as the charge-transfer resistance $\left(R_{\mathrm{T}}\right)$ and the exchange current density $\left(I_{0}\right)$. After the test electrodes were completely activated, EIS measurements were conducted at 50\% depth of discharge (DOD) using a Solartron SI1187 electrochemical interface with ZPLOT electrochemical impedance software and $1255 \mathrm{~B}$ frequency response analyzer. The EIS spectra of the electrodes were obtained in the frequency range from $100 \mathrm{kHz}$ to $10^{-2} \mathrm{~Hz}$ with alternating current amplitude of $5 \mathrm{mV}$ under open-circuit conditions. According to the analysis model proposed by Kuriyama et al. [26], an equivalent circuit for the alloy electrode was used and the parameters in the equivalent circuit were fitted using least-square method with ZVIEW electrochemical impedance software; $I_{0}$ is calculated from the following formulation $\left(I_{0}=R T / F R_{\mathrm{T}}\right)$.

\section{Result and Discussion}

3.1. $X R D$. Figure 1 shows the $\mathrm{XRD}$ patterns of $\mathrm{La}_{0.96} \mathrm{Ce}_{0.04}$ $\mathrm{Mg}_{0.15} \mathrm{Al}_{0.05} \mathrm{Ni}_{2.8}$ alloy. It can be seen that the alloy consists of a $(\mathrm{La}, \mathrm{Mg}) \mathrm{Ni}_{3}$ phase with the rhombohedral $\mathrm{PuNi}_{3}$-type structure (space group: $\mathrm{R} \overline{3} \mathrm{~m}(166)$ ) and a $\mathrm{LaNi}_{5}$ phase with the hexagonal $\mathrm{CaCu}_{5}$-type structure (space group: $\mathrm{P} 6 / \mathrm{m}^{3}$ (191)). This result coincides well with that reported by Zhang et al. [21] and Liao et al. [15]: Al was helpful to the formation of $\mathrm{LaNi}_{5}$ phase with $\mathrm{CaCu}_{5}$ type in $\mathrm{La}-\mathrm{Mg}-\mathrm{Ni}$ hydrogen storage alloys, and also the content of $\mathrm{Al}$ decides the content of $\mathrm{LaNi}_{5}$ phase. According to the literature, about 2\% Al has been used to substitute for $\mathrm{Ni}$ in the $\mathrm{La}-\mathrm{Mg}-\mathrm{Ni}$ alloy in this paper to form $\mathrm{PuNi}_{3}$-type structure and $\mathrm{CaCu}_{5}$-type structure.

The lattice parameters of $a, c$, and the cell volume of $\mathrm{LaNi}_{5}$ phase are $0.5012 \mathrm{~nm}, 0.3984 \mathrm{~nm}$, and $86.7 \times 10^{-3} \mathrm{~nm}^{3}$, respectively. Each one of those parameters is smaller than the relevant one of La-Mg-Al-Ni alloy [25] ( $a=0.5058 \mathrm{~nm}$, $b=0.4042 \mathrm{~nm}$, cell volume $=89.5 \times 10^{-3} \mathrm{~nm}^{3}$ ), respectively. According to the literature $[22,23]$, rare earth elements (such as Dy and Pr) were helpful to decrease the cell volume of $\mathrm{LaNi}_{5}$ phase, as shown in Table 1. The cell volume of $\mathrm{LaNi}_{5}$ phase without rare earth element was larger than 87 $\times 10^{-3} \mathrm{~nm}^{3}$, while it is smaller than $87 \times 10^{-3} \mathrm{~nm}^{3}$ for the alloys with rare earth element. It should be pointed out that the smaller the cell volume of the main phase $\left(\mathrm{LaNi}_{5}\right.$ phase) would decrease the cell volume expansion rate $(\Delta V / V)$ on hydriding, and it is favorable for the alloy to decrease pulverization.

3.2. TEM. Figure 2 shows the TEM and EDS micrographs of $\mathrm{La}_{0.96} \mathrm{Ce}_{0.04} \mathrm{Mg}_{0.15} \mathrm{Al}_{0.05} \mathrm{Ni}_{2.8}$ electrode alloy. It is obvious that the alloy is composed of multicrystal. The lattice space $d$ can be calculated from the following formulation $(d=\lambda L / r)$, where $L$ means the length of the camera $(0.2 \mathrm{~m}), \lambda$ means the wavelength of the accelerated voltage $(0.00370 \mathrm{~nm})$, and $r$ means the radius of the diffractive spot $(0.593 \mathrm{~cm})$. The result shows that the $d$ is $0.187 \mathrm{~nm}$.

The phase composition of the alloy has been semiquantitatively analyzed with EDS which is shown in Figure 2 and the results are shown in Table 2 . It can be seen that electrode alloy is composed of $\mathrm{La}, \mathrm{Ce}, \mathrm{Mg}, \mathrm{Al}$, and $\mathrm{Ni}$, and the content of $\mathrm{Mg}$ is $3.48 \%$ (atom), which coincide well with the designed composition of the electrode alloy.

3.3. Cycle Stability and Discharge Profile. The cycle stability of $\mathrm{La}_{0.96} \mathrm{Ce}_{0.04} \mathrm{Mg}_{0.15} \mathrm{Al}_{0.05} \mathrm{Ni}_{2.8}$ alloy electrode is shown in Figure $3(\mathrm{a})$. The alloy electrode is gradually activated during 


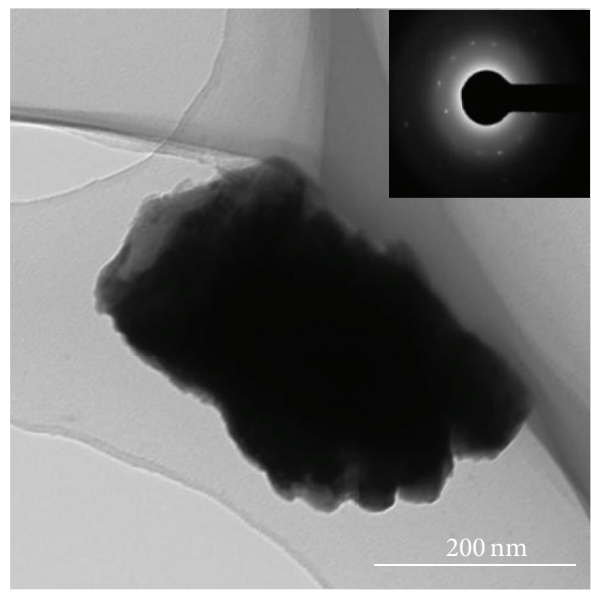

(a)

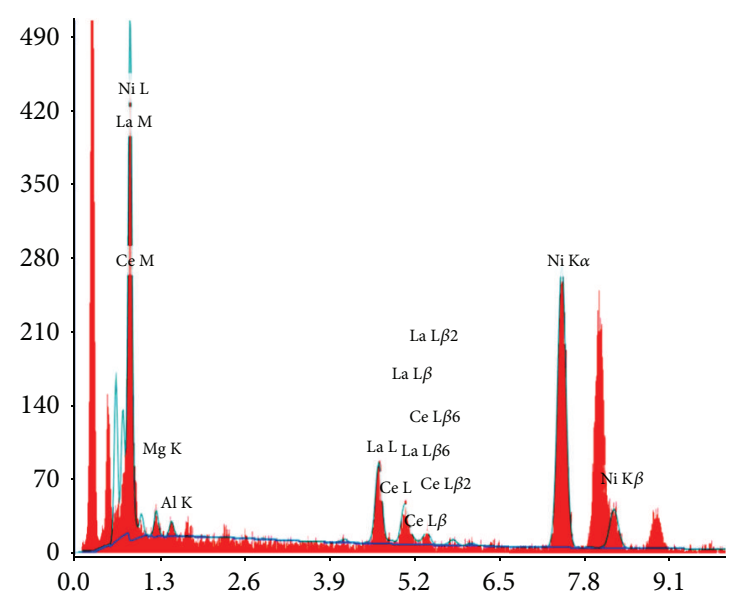

(b)

Figure 2: TEM and EDS $\mathrm{La}_{0.96} \mathrm{Ce}_{0.04} \mathrm{Mg}_{0.15} \mathrm{Al}_{0.05} \mathrm{Ni}_{2.8}$ alloy.

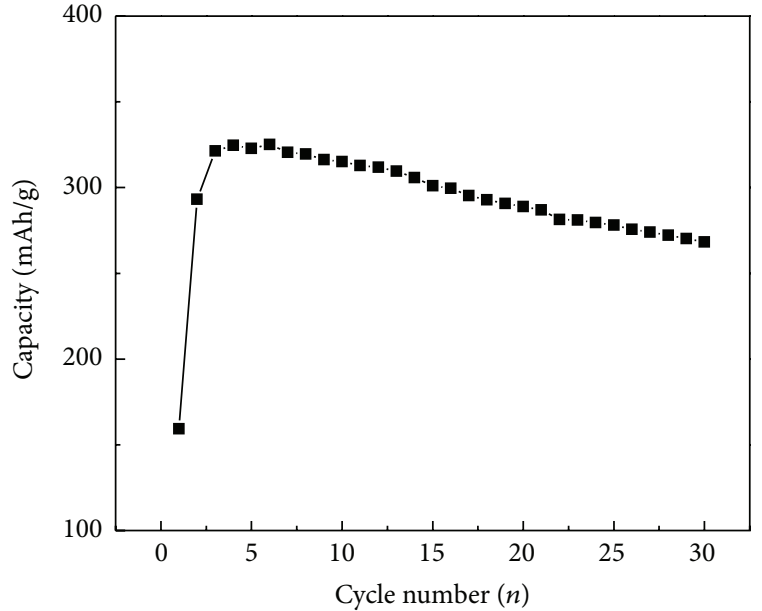

(a)

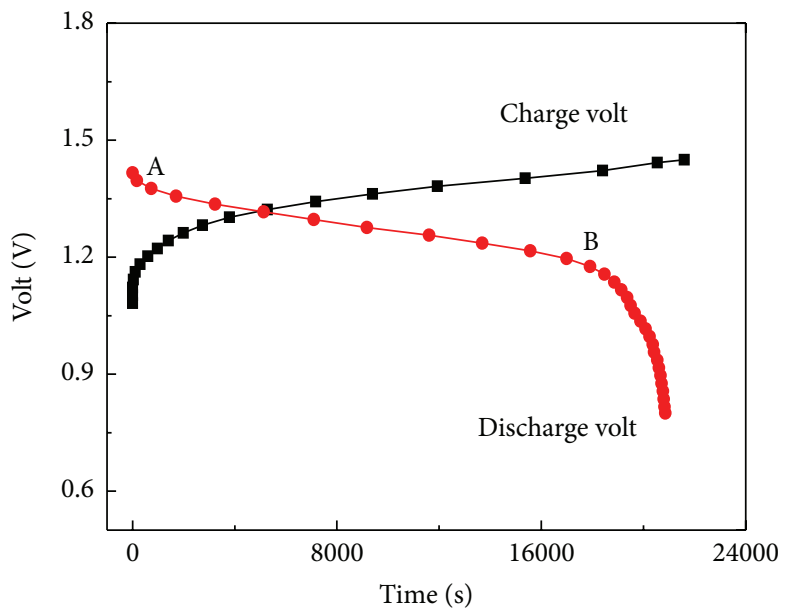

(b)

FIGURE 3: Discharge capacity and discharge profile for $\mathrm{La}_{0.96} \mathrm{Ce}_{0.04} \mathrm{Mg}_{0.15} \mathrm{Al}_{0.05} \mathrm{Ni}_{2.8}$ alloy.

charge/discharge cycle process and reached maximum discharge capacity of $325 \mathrm{mAh} \mathrm{g}^{-1}$ at 4 th cycles to be proved to have the higher electrochemical activity. According to the literature [21], $\mathrm{Al}$ was helpful to the formation of $\mathrm{LaNi}_{5}$ phase in La-Mg-Ni hydrogen storage alloys, but the content of $\mathrm{Al}$ would lead to some decrease in discharge capacity. The result also shows that the discharge capacity at 30th cycles is $268 \mathrm{mAh} \mathrm{g}^{-1}$, which is about $82.5 \%$ of the maximum discharge capacity $\left(325 \mathrm{mAhg}^{-1}\right)$, and implies that cycle stability of the alloy electrode is acceptable.

Figure 3(b) shows the typical discharge capacity-potential curves for $\mathrm{La}_{0.96} \mathrm{Ce}_{0.04} \mathrm{Mg}_{0.15} \mathrm{Al}_{0.05} \mathrm{Ni}_{2.8}$ alloy electrode. It can be clearly seen that the alloy electrode has a wider discharge voltage plateau. It is about $4.5 \mathrm{~h}$ for the battery to hold the discharge voltage above $1.2 \mathrm{~V}$ with a wider discharge voltage plateau from $1.38 \mathrm{~V}$ to 1.20 . It was reported by Iwakura et al. [27] that the curve of equilibrium potentialdischarge capacity and the curve of $\mathrm{P}-\mathrm{C}$ isotherm were rather coordinate, especially for the tendency of the plateau region; that was to say, the plateau region of equilibrium potential for $\mathrm{La}_{0.96} \mathrm{Ce}_{0.04} \mathrm{Mg}_{0.15} \mathrm{Al}_{0.05} \mathrm{Ni}_{2.8}$ alloy electrode has a good discharge characteristics.

\subsection{Temperature Effect and High-Rate Dischargeability.} Figure 4(a) shows the dependence of the discharge capacity of $\mathrm{La}_{0.96} \mathrm{Ce}_{0.04} \mathrm{Mg}_{0.15} \mathrm{Al}_{0.05} \mathrm{Ni}_{2.8}$ alloy electrode on different temperatures. As can be seen in the figure, the discharge capacity of the alloy electrode is decreased as the temperature increased from $303 \mathrm{~K}$ to $333 \mathrm{~K}$. For example, the discharge capacity of the alloy electrode is $284 \mathrm{mAh} \mathrm{g}^{-1}$ and $263 \mathrm{mAh} \mathrm{g}^{-1}$ at $323 \mathrm{~K}$ and at $333 \mathrm{~K}$, respectively. It implies that the discharge capacity of $\mathrm{La}_{0.96} \mathrm{Ce}_{0.04} \mathrm{Mg}_{0.15} \mathrm{Al}_{0.05} \mathrm{Ni}_{2.8}$ alloy electrode is sensitive to temperature within the temperature span.

HRD is an important property of electrode alloy used as negative electrode material in Ni-MH battery, especially 
TABLE 1: Lattice constant and cell volume for La-RE-Mg-Al-Ni phydrogen storage alloys [22, 23, 25].

\begin{tabular}{lllc}
\hline Alloy & $\mathrm{a} / \mathrm{nm}$ & $\mathrm{c} / \mathrm{nm}$ & \\
\hline La-Mg-Al-Ni & 0.5058 & 0.4042 & $0.30^{-3} / \mathrm{nm}^{3}$ \\
$\mathrm{La}-\mathrm{Ce}-\mathrm{Mg}-\mathrm{Al}-\mathrm{Ni}$ & 0.5012 & 0.3984 & 89.5 \\
$\left(\mathrm{La}_{1-x} \mathrm{Dy}\right)_{0.8} \mathrm{Mg}_{0.2} \mathrm{Ni}_{3.4} \mathrm{Al}_{0.1}(x=0)$ & 0.5024 & 0.3982 & 86.7 \\
$\left(\mathrm{La}_{1-x} \mathrm{Dy}_{x}\right)_{0.8} \mathrm{Mg}_{0.2} \mathrm{Ni}_{3.4} \mathrm{Al}_{0.1}(x=0.05)$ & 0.5019 & 0.3978 & 87.0 \\
$\left(\mathrm{La}_{1-x} \mathrm{Dy}_{x}\right)_{0.8} \mathrm{Mg}_{0.2} \mathrm{Ni}_{3.4} \mathrm{Al}_{0.1}(x=0.2)$ & 0.4993 & 0.3909 & 86.8 \\
$\mathrm{La}_{0.8-x} \mathrm{Pr}_{x} \mathrm{Mg}_{0.2} \mathrm{Ni}_{3.8}(x=0)$ & 0.5028 & 0.3989 & 84.4 \\
$\mathrm{La}_{0.8-x} \operatorname{Pr}_{x} \mathrm{Mg}_{0.2} \mathrm{Ni}_{3.8}(x=0.15)$ & 0.5012 & 0.3983 & 87.3 \\
$\mathrm{La}_{0.8-x} \operatorname{Pr}_{x} \mathrm{Mg}_{0.2} \mathrm{Ni}_{3.8}(x=0.40)$ & 0.4998 & 0.3982 & 86.7 \\
\hline
\end{tabular}

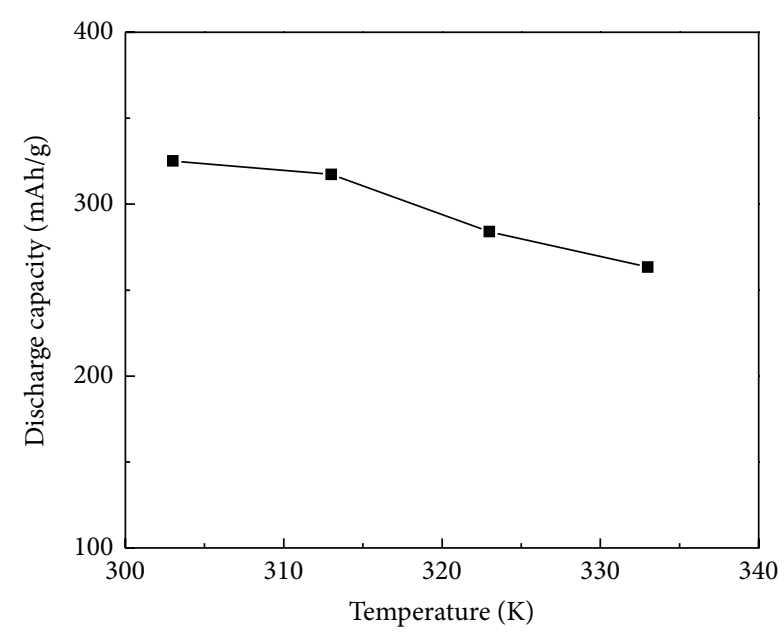

(a)

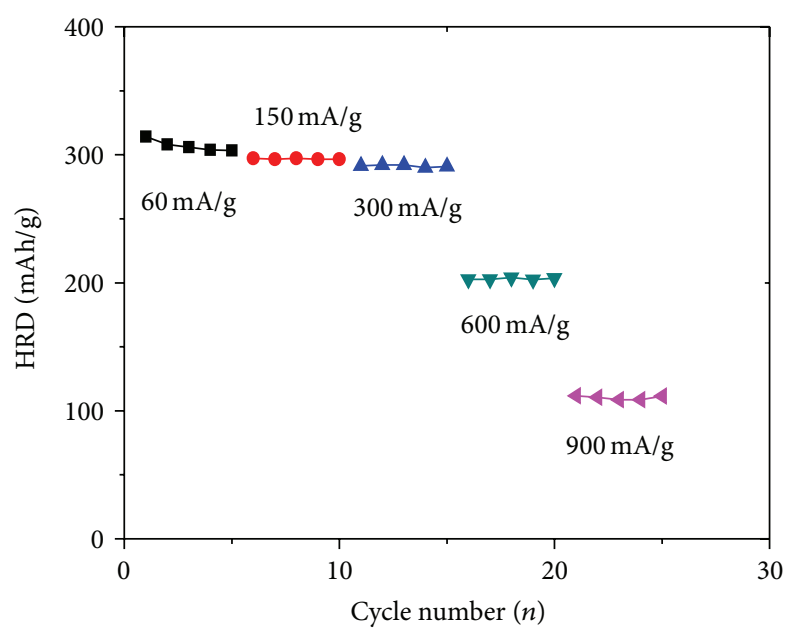

(b)

FIGURE 4: Effect of temperature and discharge current density on the discharge capacity for $\mathrm{La}_{0.96} \mathrm{Ce}_{0.04} \mathrm{Mg}_{0.15} \mathrm{Al}_{0.05} \mathrm{Ni}_{2.8}$ alloy.

TABle 2: Phase composition and interplanar distance for $\mathrm{La}_{0.24} \mathrm{Ce}_{0.01} \mathrm{Mg}_{0.04} \mathrm{Al}_{0.01} \mathrm{Ni}_{0.70}$ alloy.

\begin{tabular}{|c|c|c|c|c|c|}
\hline \multicolumn{5}{|c|}{ Composition (atom \%) } & \multirow{2}{*}{$d(\mathrm{~nm})$} \\
\hline $\mathrm{La}$ & $\mathrm{Ce}$ & $\mathrm{Mg}$ & $\mathrm{Al}$ & $\mathrm{Ni}$ & \\
\hline 23.93 & 1.29 & 3.48 & 1.47 & 69.82 & 0.187 \\
\hline
\end{tabular}

used in electric vehicles. Figure 4(b) shows the relationship between the discharge capacity and the discharge current density of $\mathrm{La}_{0.96} \mathrm{Ce}_{0.04} \mathrm{Mg}_{0.15} \mathrm{Al}_{0.05} \mathrm{Ni}_{2.8}$ alloy electrode. It can be clearly seen that the alloy electrode has higher discharge capacity within the discharge current density span from $60 \mathrm{~mA} \mathrm{~g}^{-1}$ to $300 \mathrm{~mA} \mathrm{~g}^{-1}$, and the cycle stability of alloy electrode is accepted. It is worthy of notice that the discharge capacity of the alloy electrode is higher than $200 \mathrm{mAh} \mathrm{g}^{-1}$ at $600 \mathrm{~mA} \mathrm{~g}^{-1}$ and $100 \mathrm{mAh} \mathrm{g}^{-1}$ at $900 \mathrm{~mA} \mathrm{~g}^{-1}$, respectively. This characteristic of the alloy is crucial for it to be used as a negative electrode material of $\mathrm{Ni}-\mathrm{MH}$ batteries.

3.5. EIS. Figure 5 shows the EIS of $\mathrm{La}_{0.96} \mathrm{Ce}_{0.04} \mathrm{Mg}_{0.15} \mathrm{Al}_{0.05}$ $\mathrm{Ni}_{2.8}$ alloy electrode at $50 \%$ DOD. EIS has been used for determining $R_{\mathrm{T}}$ and $I_{0}$ to clarify the kinetic properties of dehydrating action at $303 \mathrm{~K}$. According to the equivalent circuits [26], the large semicircle in the low-frequency region

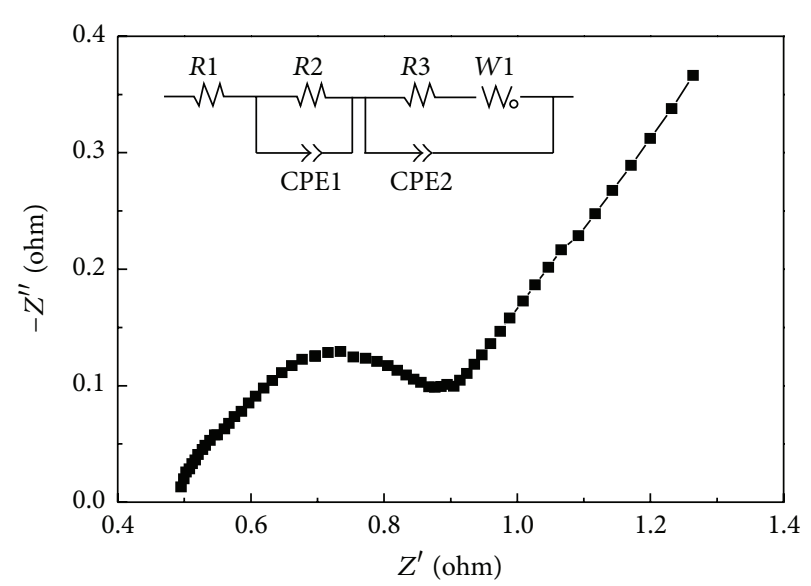

Figure 5: EIS of $\mathrm{La}_{0.96} \mathrm{Ce}_{0.04} \mathrm{Mg}_{0.15} \mathrm{Al}_{0.05} \mathrm{Ni}_{2.8}$ alloy electrode at $50 \%$ DOD.

is attributed to the charge transfer resistance $R_{\mathrm{T}}$ on the alloy surface, and the fitted result shows that the $R_{\mathrm{T}}$ is $0.135 \Omega$. The exchange current density $I_{0}$ for the alloy electrode can be calculated by the following formulation: $I_{0}=R T / F R_{\mathrm{T}}$, where $R, T, F$, and $R_{\mathrm{T}}$ denote the gas constant, the absolute temperature, the Faraday constant, and charge transfer resistance on 
TABLE 3: Self-discharge characteristics of $\mathrm{La}_{0.96} \mathrm{Ce}_{0.04} \mathrm{Mg}_{0.15} \mathrm{Al}_{0.05} \mathrm{Ni}_{2.8}$ alloy electrode at $293 \mathrm{~K}$.

\begin{tabular}{lcccccc}
\hline Day & $C_{1} / \mathrm{mAh}^{-1}$ & $C_{2} / \mathrm{mAhg}^{-1}$ & $C_{3} / \mathrm{mAhg}^{-1}$ & $C_{1}-C_{3} / \mathrm{mAhg}^{-1}$ & $C_{3}-C_{2} / \mathrm{mAhg}^{-1}$ & Self-discharge rate $/ \%$ \\
\hline 1 & 296.1 & 283.3 & 293.2 & 2.9 & 9.9 & 3.9 \\
2 & 287.5 & 270.8 & 383.1 & 4.4 & 12.3 & 5.1 \\
4 & 278.9 & 190.3 & 258.2 & 20.7 & 67.9 & 7.3 \\
\hline
\end{tabular}

the alloy surface, respectively. The calculated result shows that $I_{0}$ is $1298 \mathrm{~mA} \mathrm{~g}^{-1}$, which is much larger than that in $V$-based solid solution electrode alloy [28]. This may be responsible for the better high-rate dischargeability.

3.6. Self-Discharge. According to the literature [29], selfdischarge of the hydrogen storage alloy can be divided into two parts, the reversible $\left(C_{3}-C_{2}\right)$ and irreversible $\left(C_{1}-C_{3}\right)$, respectively. The self-discharge rate of the alloy electrode can be calculated with $\left\{1-2 C_{2} /\left(C_{1}+C_{3}\right)\right\} \times 100 \%$ day. $C_{1}, C_{2}$, and $C_{3}$ have been determined with the tested alloy electrode standing at open circuit for 1, 2, and 4 days, respectively, as shown in Table 3. The results indicate that the self-discharge rate of the alloy electrode is increased as the time standing increased from 1 day to 4 days, also, the reversible part $\left(C_{3^{-}}\right.$$C_{2}$ ) which due to desorption of hydrogen is larger than that of irreversible $\left(C_{1}-C_{3}\right)$ part which was due to deterioration of the hydrogen storage alloy.

\section{Conclusion}

The structure and electrochemical properties of $\mathrm{La}_{0.96} \mathrm{Ce}_{0.04}$ $\mathrm{Mg}_{0.15} \mathrm{Al}_{0.05} \mathrm{Ni}_{2.8}$ alloy electrode have been studied. The conclusions can be drawn as follows.

(1) The hydrogen storage alloy is consisted of a (La, $\mathrm{Mg}) \mathrm{Ni}_{3}$ phase with the rhombohedral $\mathrm{PuNi}_{3}$-type structure and a $\mathrm{LaNi}_{5}$ phase with the hexagonal $\mathrm{CaCu}_{5}$-type structure.

(2) The maximum discharge capacity $325 \mathrm{mAh} \mathrm{g}^{-1}$ and cyclic stability $82.5 \%$ after 30 cycles are obtained; the discharge capacity is decreased as the temperature increased from $303 \mathrm{~K}$ to $333 \mathrm{~K}$; the alloy electrode has higher discharge capacity within the discharge current density span from $60 \mathrm{~mA} \mathrm{~g}^{-1}$ to $300 \mathrm{~mA} \mathrm{~g}^{-1}$.

(3) The charge transfer resistance $R_{\mathrm{T}}$ on the alloy surface is $0.135 \Omega$ and the exchange current density $I_{0}$ is $1298 \mathrm{~mA} \mathrm{~g}^{-1}$, respectively.

(4) The self-discharge rate of the alloy electrode is increased as the time standing increases (increased), and also the reversible part $\left(C_{3}-C_{2}\right)$ is larger than that of irreversible $\left(C_{1}-C_{3}\right)$ part.

\section{Conflict of Interests}

The authors declare that they have no conflict of interests.

\section{Acknowledgments}

This work was supported by Ministry of Science and Technology of China (2011AA03A408), the Foundation of State Key Laboratory of Rare Earth Resources Utilization (RERU2013021), and Doctoral Foundation of Yanshan University (B330).

\section{References}

[1] J. J. Liu, S. M. Han, Y. Li et al., "Phase structure and electrochemical characteristics of high-pressuresintered $\mathrm{La}-\mathrm{Mg}-\mathrm{Ni}$-based hydrogen storage alloys," Electrochimica Acta, vol. 111, pp. 18-24, 2013.

[2] L. Zhang, S. M. Han, Y. Li et al., "Formation mechanism, phase structure and electrochemical properties of the $\mathrm{La}-\mathrm{Mg}-$ Ni-based multiphase alloys by powder sintering $\mathrm{LaNi}_{5}$ and $\mathrm{LaMgNi}_{4}$," International Journal of Hydrogen Energy, vol. 38, no. 25, pp. 10431-10437, 2013.

[3] J. L. Zhang, S. M. Han, Y. Li et al., "Effects of $\mathrm{PuNi}_{3}$ and $\mathrm{Ce}_{2} \mathrm{Ni}_{7}-$ type phase abundance on electrochemical characteristics of LaMg-Ni-based alloys," Journal of Alloys and Compounds, vol. 581, pp. 693-698, 2013.

[4] C. C. Nwakwuo, T. Holm, R. V. Denys et al., "Effect of magnesium content and quenching rate on the phase structure and composition of rapidly solidified $\mathrm{La}_{2} \mathrm{MgNi}_{9}$ metal hydride battery electrode alloy," Journal of Alloys and Compounds, vol. 555, pp. 201-208, 2013.

[5] Y. H. Zhang, Z. H. Hou, B. W. Li, H. P. Ren, G. F. Zhang, and D. L. Zhao, "An investigation on electrochemical hydrogen storage performances of the as-cast and -annealed $\mathrm{La}_{0.8-x} \mathrm{Sm}_{x} \mathrm{Mg}_{0.2} \mathrm{Ni}_{3.35} \mathrm{Al}_{0.1} \mathrm{Si}_{0.05}(\mathrm{x}=0-0.4)$ alloys," Journal of Alloys and Compounds, vol. 537, pp. 175-182, 2013.

[6] B. P. Wang, Y. Z. Chen, and Y. N. Liu, "Structure and electrochemical properties of $\left(\mathrm{La}_{1-x} \mathrm{Dy}_{x}\right)_{0.8} \mathrm{Mg}_{0.2} \mathrm{Ni}_{3.4} \mathrm{Al}_{0.1}$ ( $x$ $=0.0-0.20$ ) hydrogen storage alloys," International Journal of Hydrogen Energy, vol. 37, no. 11, pp. 9082-9087, 2012.

[7] H. X. Huang and K. L. Huang, "Effect of $A B_{5}$ alloy on electrochemical properties of $\mathrm{Mm}_{0.80} \mathrm{Mg}_{0.20} \mathrm{Ni}_{2.56} \mathrm{Co}_{0.50} \mathrm{Mn}_{0.14} \mathrm{Al}_{0.12}$ hydrogen storage alloy," Powder Technology, vol. 221, pp. 365370, 2012.

[8] X. P. Dong, L. Y. Yang, X. T. Li, Q. Wang, L. H. Ma, and Y. F. Lin, "Effect of substitution of aluminum for nickel on electrochemical properties of $\mathrm{La}_{0.75} \mathrm{Mg}_{0.25} \mathrm{Ni}_{3.5-x} \mathrm{Co}_{0.2} \mathrm{Al}_{x}$ hydrogen storage alloys," Journal of Rare Earths, vol. 29, no. 2, pp. 143-149, 2011.

[9] Y. H. Zhang, Y. Cai, C. Zhao, T. T. Zhai, G. F. Zhang, and D. L. Zhao, "Electrochemical performances of the as-melt La ${ }_{0.75-x} \mathrm{M}_{x} \mathrm{Mg}_{0.25} \mathrm{Ni}_{3.2} \mathrm{Co}_{0.2} \mathrm{Al}_{0.1}(\mathrm{M}=\mathrm{Pr}, \mathrm{Zr}, x=0,0.2)$ alloys applied to $\mathrm{Ni}$ /metal hydride $(\mathrm{MH})$ battery," International Journal of Hydrogen Energy, vol. 37, no. 19, pp. 14590-14597, 2012.

[10] Y. Liu, Y. Cao, L. Huang, M. Gao, and H. Pan, "Rare earth-MgNi-based hydrogen storage alloys as negative electrode materials for Ni/MH batteries," Journal of Alloys and Compounds, vol. 509, no. 3, pp. 675-686, 2011. 
[11] K. Kadir, T. Sakai, and I. Uehara, "Synthesis and structure determination of a new series of hydrogen storage alloys; $\mathrm{RMg}_{2} \mathrm{Ni}_{9}\left(\mathrm{R}=\mathrm{La}, \mathrm{Ce}, \mathrm{Pr}, \mathrm{Nd}, \mathrm{Sm}\right.$ and Gd) built from $\mathrm{MgNi}_{2}$ laves-type layers alternating with $\mathrm{AB}_{5}$ layers," Journal of Alloys and Compounds, vol. 257, no. 1-2, pp. 115-121, 1997.

[12] K. Kadir, N. Kuriyama, T. Sakai, I. Uehara, and L. Eriksson, "Structural investigation and hydrogen capacity of $\mathrm{CaMg}_{2} \mathrm{Ni}_{9}$ : a new phase in the $\mathrm{AB}_{2} \mathrm{C}_{9}$ system isostructural with $\mathrm{LaMg}_{2} \mathrm{Ni}_{9}$," Journal of Alloys and Compounds, vol. 284, no. 1-2, pp. 145-154, 1999.

[13] K. Kadir, T. Sakai, and I. Uehara, "Structural investigation and hydrogen storage capacity of $\mathrm{LaMg}_{2} \mathrm{Ni}_{9}$ and $\left(\mathrm{La}_{0.65}\right.$ $\left.\mathrm{Ca}_{0.35}\right)\left(\mathrm{Mg}_{1.32} \mathrm{Ca}_{0.68}\right) \mathrm{Ni}_{9}$ of the $\mathrm{AB}_{2} \mathrm{C}_{9}$ type structure," Journal of Alloys and Compounds, vol. 302, no. 1-2, pp. 112-117, 2000.

[14] J. Chen, H. T. Takeshita, H. Tanaka et al., "Hydriding properties of $\mathrm{LaNi}_{3}$ and $\mathrm{CaNi}_{3}$ and their substitutes with $\mathrm{PuNi}_{3}$-type structure," Journal of Alloys and Compounds, vol. 302, no. 1-2, pp. 304-313, 2000.

[15] B. Liao, Y. Q. Lei, L. X. Chen, G. L. Lu, H. G. Pan, and Q. D. Wang, "The structural and electrochemical properties of $\mathrm{La}_{2}$ $\mathrm{Mg}\left(\mathrm{Ni}_{0.8-x} \mathrm{Co}_{0.2} \mathrm{Al}_{x}\right)_{9}(\mathrm{x}=0-0.03)$ hydrogen storage electrode alloys," Journal of Alloys and Compounds, vol. 415, no. 1-2, pp. 239-243, 2006.

[16] B. Liao, Y. Q. Lei, L. X. Chen, G. L. Lu, H. G. Pan, and Q. D. Wang, "Effect of the $\mathrm{La} / \mathrm{Mg}$ ratio on the structure and electrochemical properties of $\mathrm{La}_{x} \mathrm{Mg}_{3-x} \mathrm{Ni}_{9}(\mathrm{x}=1.6-2.2)$ hydrogen storage electrode alloys for nickel-metal hydride batteries," Journal of Power Sources, vol. 129, no. 2, pp. 358-367, 2004.

[17] H. Miao, H. Pan, S. C. Zhang, N. Chen, R. Li, and M. X. Gao, "Influences of Co substitution and annealing treatment on the structure and electrochemical properties of hydrogen storage alloys $\mathrm{La}_{0.7} \mathrm{Mg}_{0.3} \mathrm{Ni}_{2.45-x} \mathrm{Co}_{0.75+x} \mathrm{Mn}_{0.1} \mathrm{Al}_{0.2}(x=0.00,0.15,0.30)$," International Journal of Hydrogen Energy, vol. 32, no. 15, pp. 3387-3394, 2007.

[18] H. G. Pan, Y. F. Liu, M. X. Gao, R. Li, and Y. Q. Lei, "Function of cobalt in the new type rare-earth Mg-based hydrogen storage electrode alloys," Intermetallics, vol. 13, no. 7, pp. 770-777, 2005.

[19] B. Liao, Y. Q. Lei, L. X. Chen, G. L. Lu, H. G. Pan, and Q. D. Wang, "Effect of Co substitution for $\mathrm{Ni}$ on the structural and electrochemical properties of $\mathrm{La}_{2} \mathrm{Mg}\left(\mathrm{Ni}_{1-x} \mathrm{Co}_{x}\right)_{9}(x=0.1-0.5)$ hydrogen storage electrode alloys," Electrochimica Acta, vol. 50, no. 4, pp. 1057-1063, 2004.

[20] B. Liao, Y. Q. Lei, L. X. Chen, G. L. Lu, H. G. Pan, and Q. D. Wang, "The effect of $\mathrm{Al}$ substitution for Ni on the structure and electrochemical properties of $\mathrm{AB}_{3}$-type $\mathrm{La}_{2} \mathrm{Mg}\left(\mathrm{Ni}_{1-x} \mathrm{Al}_{x}\right)_{9}(x=$ 0-0.05) alloys," Journal of Alloys and Compounds, vol. 404-406, pp. 665-668, 2005.

[21] X.-Y. Zhang, Y.-C. Luo, D.-H. Wang, R.-X. Yan, Y. Zhang, and L. Kang, "A study on the structure and electrochemical properties of $\mathrm{La}_{0.67} \mathrm{Mg}_{0.33} \mathrm{Ni}_{3.0-x} \mathrm{Al}_{x}(\mathrm{x}=0,0.1,0.2,0.3)$ hydrogen storage alloys," Journal of Functional Materials, vol. 36, no. 7, pp. 10341040, 2005.

[22] B. P. Wang, Y. Z. Chen, and Y. N. Liu, "Structure and electrochemical properties of $\left(\mathrm{La}_{1-x} \mathrm{Dy}_{x}\right)_{0.8} \mathrm{Mg}_{0.2} \mathrm{Ni}_{3.4} \mathrm{Al}_{0.1} \quad(x=$ $0.0-0.20)$ hydrogen storage alloys," International Journal of Hydrogen Energy, vol. 37, no. 11, pp. 9082-9087, 2012.

[23] J. B. Fan, A. Q. Deng, G. J. Xia, K. N. Qian, and Y. C. Luo, "Phase structure and electrochemical properties of the $\mathrm{AB}_{3.8}$-type La$\mathrm{Mg}-\mathrm{Ni}$ system hydrogen storage alloys," Rare Metal Materials and Engineering, vol. 39, no. 12, pp. 2142-2146, 2010.

[24] Y. Q. Qiao, M. S. Zhao, X. J. Zhu, and G. Cao, "Microstructure and some dynamic performances of $\mathrm{Ti}_{0.17} \mathrm{Zr}_{0.08} \mathrm{~V}_{0.34} \mathrm{RE}_{0.01}$
$\mathrm{Cr}_{0.1} \mathrm{Ni}_{0.3}(\mathrm{RE}=\mathrm{Ce}, \mathrm{Dy})$ hydrogen storage electrode alloys," International Journal of Hydrogen Energy, vol. 32, no. 15, pp. 3427-3434, 2007.

[25] H. Miao, H. Pan, S. Zhang, N. Chen, R. Li, and M. Gao, "Influences of Co substitution and annealing treatment on the structure and electrochemical properties of hydrogen storage alloys $\mathrm{La}_{0.7} \mathrm{Mg}_{0.3} \mathrm{Ni}_{2.45-x} \mathrm{Co}_{0.75+x} \mathrm{Mn}_{0.1} \mathrm{Al}_{0.2}(x=0.00,0.15,0.30)$," International Journal of Hydrogen Energy, vol. 32, no. 15, pp. 3387-3394, 2007.

[26] N. Kuriyama, T. Sakai, H. Miyamura, I. Uehara, H. Ishikawa, and T. Iwasaki, "Electrochemical impedance and deterioration behavior of metal hydride electrodes," Journal of Alloys and Compounds, vol. 202, no. 1-2, pp. 183-197, 1993.

[27] C. Iwakura, T. Askahiko, H. Yoneyama, T. Sakai, K. Oguro, and H. Ishikawa, "Electrochemical characteristics of $\mathrm{LaNi}_{5}$ system hydrogen-absorbing alloys as negative electrode materials for nickel-hydrogen batteries," The Chemical Society of Japan, vol. 8, pp. 1482-1488, 1988.

[28] Y. Q. Qiao, M. S. Zhao, M. Y. Li, X. J. Zhu, and G. Y. Cao, "Microstructure and electrochemical performance of $\mathrm{Ti}_{0.17}$ $\mathrm{Zr}_{0.08} \mathrm{~V}_{0.34} \mathrm{Pd}_{0.01} \mathrm{Cr}_{0.1} \mathrm{Ni}_{0.3}$ electrode alloy," Scripta Materialia, vol. 55, no. 3, pp. 279-282, 2006.

[29] C. Iwakura, Y. Kajiya, H. Yoneyama, T. Saki, K. Oguro, and H. Ishikawa, "Self-discharge mechanism of nickel-hydrogen batteries using metal hydride anodes," Journal of the Electrochemical Society, vol. 136, no. 5, pp. 1351-1355, 1989. 

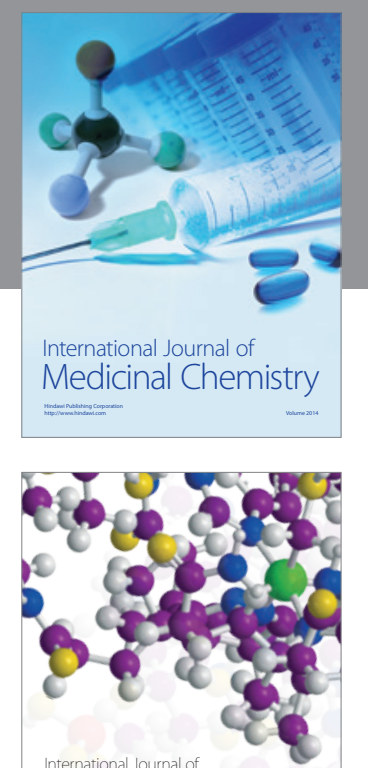

\section{Carbohydrate} Chemistry

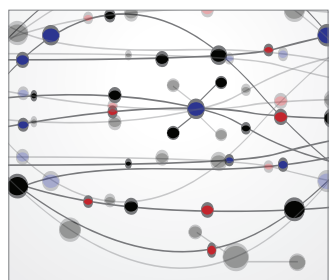

The Scientific World Journal
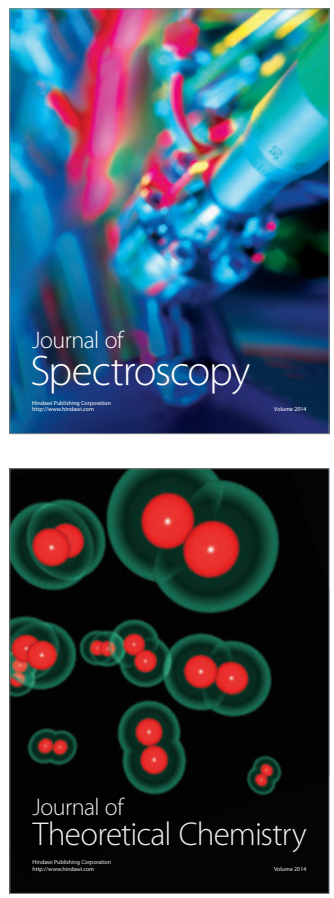
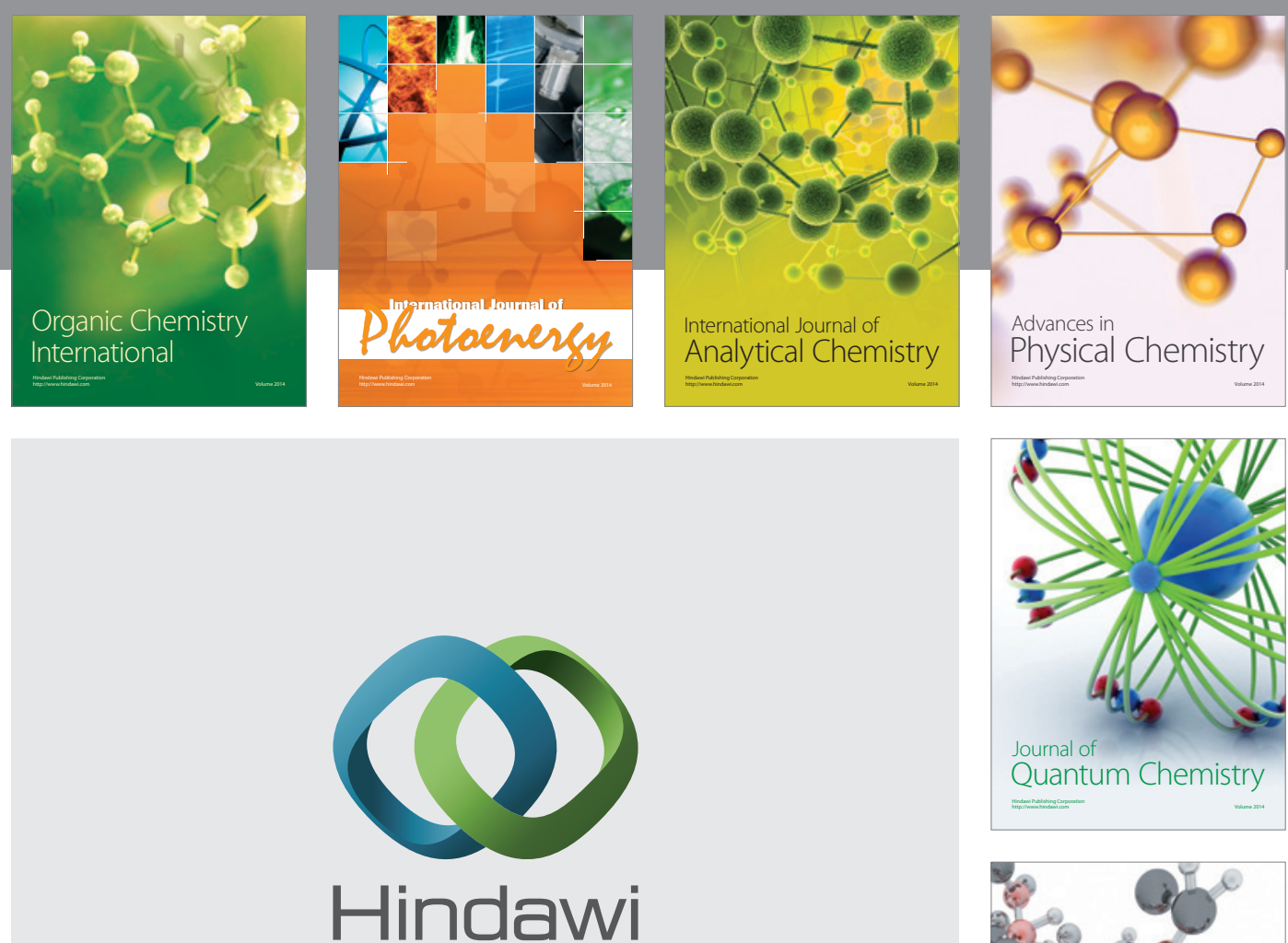

Submit your manuscripts at

http://www.hindawi.com

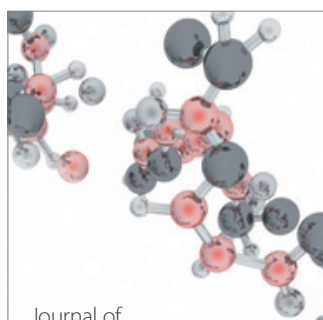

Analytical Methods

in Chemistry

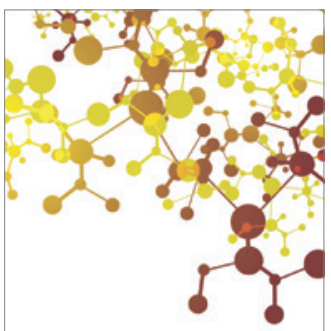

Journal of

Applied Chemistry

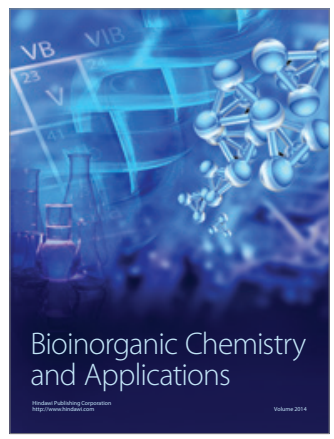

Inorganic Chemistry
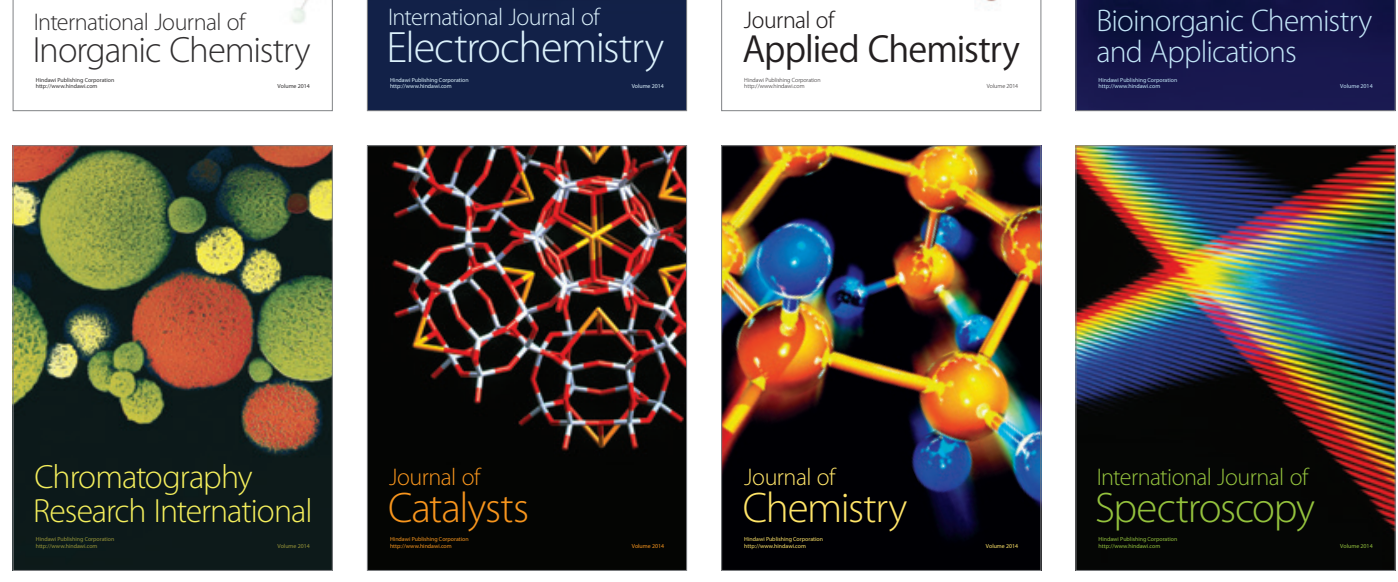